\title{
Effect of Leptadeniahastata ETHANOLIC Extract in Wistar Rats
}

\author{
Bakodo, Pwainginomi Confidence ${ }^{1}$, Nadro, Margaret Samuel ${ }^{2}$, Panuel, Boniface ${ }^{3}$ \\ ${ }^{1}$ Government Day Senior Secondary School, Mbamba Yola South L G A, Adamawa state. \\ ${ }^{2}$ Department of Biochemistry ModibboAdama University of Technology, Yola \\ ${ }^{3}$ Da'ama Specialist Hospital No.70/72 Abubakar way, Jimetayola. Adamawa state
}

\begin{abstract}
Leptadeniahastata(Pers.) Decneis edible non-domesticated vegetable and it is used in the treatment of diabetes, hypertension, skin diseases catarrh, prostate and rheumatism.This study was designed to investigate the effect of ethanol extract of Leptadeniahastataon wistarrats. Acute and chronic toxicity were conducted. The acute toxicity study of ethanol extract of Leptadeniahastata showed no toxicity when administered up to $5000 \mathrm{mg} / \mathrm{kg}$ body weight orally. In the chronic toxicity study, different doses of the ethanol extract were administered to rats at $100 \mathrm{mg} / \mathrm{kg}$ body weight, $200 \mathrm{mg} / \mathrm{kg}$ body weight and $400 \mathrm{mg} / \mathrm{kg}$ body weight for 30 consecutive days. The levels of serum AST and ALT of treated animals significantly $(p<0.05)$ decreased compared to the control group. The serum albumin of treated animals showed significant $(p<0.05)$ increase compared to the control group. There was significant decrease in the serum levels of urea of the treated animals compared to the control, also significant increase $(p<0.05)$ in PCV and $\mathrm{Hb}$ were observed in the treated animals compared to the control. The result therefore suggests that Leptadeniahastata could be safe for consumption orally even at chronic administration.
\end{abstract}

Keywords: Leptadenia hastata, acute toxicity, chronic toxicity, wistar rats and haematology

\section{Introduction}

The liver plays a significant role in the body as the organ responsible for metabolism of toxic substances that enter the body (Alisiet al., 2008). The major functions of the liver can be detrimentally altered by liver injury resulting from acute or chronic exposure to toxicants or by situations affecting both $\beta$-oxidation and the respiratory chain enzymes (Alisiet al., 2008). Serum enzyme activities are used as indicators of chemically induced liver damage (Drotman and Lawhorn, 1978). Hepatotoxicity has been viewed as liver injury associated with impaired liver function caused by exposure to drug or other noninfectious agents (Navarro, 2006). The Kidney performs the functions of getting rid of the body's waste materials that are either ingested, produced by metabolism or because of detoxification of the liver. This, and other functions of the kidney, can be disrupted by accumulation of toxic metabolites or chemicals leading to renal diseases (Arthur and John, 2000).

Leptadeniahastata(Pers.) Decne, is a perennial plant of the family of Asclepediaceae which pushes in cattle breeding areas of Burkina Faso and some other parts of West Africa. Leptadeniahastatais described as a climber or crawling plant with white soft grooved stem, simple green paired dehiscent leaves with pale under surface latex white and grows at riverine areas (Hutchinson and Dalziel, 1937). The breeders commonly used the leaf stems for their parasitic activity and against placental retention when animals gave birth (Kerharo and Adam, 1974; Arbonnier, 2000). Literature survey and ethno botanical investigations with the traditional healers revealed that the consumption of the leaf stems of Leptadeniahastataby the donkeys, the horses and the dromedaries had anti-fertility effect (Bayalaet al., 2011). In the North region of Burkina Faso, it was arisen that the consumption of Leptadeniahastatahad harmful effects on fertility of the sheep and goats. In certain areas of West
Africa, breeders claimed the anti-fertility effect of their animals after consumption of Leptadeniahastataleaf stems (Berhaut, 1979; Arbonnier, 2000). It is commonly used as a vegetable and is considered as a famine food in Niger republic due to its high content of valuable nutrients rich in various types of amino acids, fatty acids, terpenes, carotenes, luteines and poly-oxy pregnane (Aquino et al., 1996; Freibergeret al., 1998; Nikiemaet al., 2001; Senaet al., 1998).

\section{Materials and Methods}

\section{Plant material}

Leptadeniahastataplant was collected in the wild area of Yola South local government area of Adamawa State. The plant specimen was identified and authenticated at the Department of Plant Science, ModibboAdama University of Technology, Yola. Adamawa State.

\section{Animals}

Adult albino rats were procured from Veterinary Research Institute Vom, Plateau state. The animals were housed in a cage and maintained under standard laboratory conditions. They were given vital feeds and water. They were acclimatized for one week and were fasted over night with free access to water prior the experiments. The animals were handled in accordance with international principles guiding the use and handling of experimental animals (United State National Institute for health, 1985).

\section{Methods}

\section{Extract preparation}

The plant Leptadeniahastatawas washed and shade dried for one week, made into fine powder using a pestle and mortar, and passed through a $2 \mathrm{~mm}$ mesh sieve to obtain finer 


\section{International Journal of Science and Research (IJSR) \\ ISSN (Online): 2319-7064}

Index Copernicus Value (2013): 6.14 | Impact Factor (2014): 5.611

powder. The powdered sample was stored in an airtight bottle for further use (Handa, 2008).

\section{Extraction process}

Ethanol extract: Fifty grams of the powdered sample was soaked in $500 \mathrm{ml}$ of the solvent and allowed to stand for 24 hours. The mixture was stirred occasionally. After 24 hours, the sample was double-filtered using cheese cloth and collected in a conical flask. The filtrate was dried in hot-air oven at temperature of $45^{\circ} \mathrm{C}$ (Handa, 2008).

\section{Acute Toxicity Study}

\section{Experimental Design}

Thirty-five adult albino male rats weighing between 100$120 \mathrm{~g}$ were used and were divided into seven groups of five rats each and were treated with the extract at doses of 100 , $500,1000,2000,3000$ and $5000 \mathrm{mg} / \mathrm{kg}$ body weight. Oral administration of these doses was done for 3 days where the rats were given the plant extracts, according to the OECD guideline (Organization for Economic Co-operation and Development, Guideline- 425, adopted on 3rd October, 2008). The animals were observed closely for general toxicity signs, behavioural changes, and mortality were recorded within $72 \mathrm{~h}$.

\section{Chronic toxicity study}

Twenty-four male rats weighing between 100-120g were used and were divided into four groups of six rats each and were treated with the extract at doses of 100, 200 and 400 $\mathrm{mg} / \mathrm{kg}$ of the extract. The doses were administered orally daily for a period of 30 days.

\section{Biochemical parameters}

The effect of the extract on biochemical parameters were examined and compared with those of the control group. The blood samples collected with heparinized bottles were centrifuged at $5000 \mathrm{rpm}$ for 10 minutes to obtain clear plasma for the following investigations: Total, and direct bilirubin were determined using Jandrassik and Grof technique (1938) describe by Doumaset al., 1985; alanine amino transferase (ALT) and aspartate amino transferase (AST) were measured by using enzymatic method Reitman and Frankel (1957); alkaline phosphatase (ALP) was analyzed according to the method of Bormers and McComb (1975); total protein (TP) concentration was determined by Biuret method Reinhold (1953); albumin was determined based on its reaction with bromocresol green (Binding method) (Spencer and Price, 1971); urea was determined according to Urease-Berthelot method (Weatherburn, 1967) and plasma creatinine was estimated using Jaffe reaction, (1974).

\section{Some heamatological parameters}

The blood samples were analyzed for the haemoglobin $(\mathrm{Hb})$ content was by Cyanmethaemoglobin (Drabkin) method (Dacie and Lewis, 1984); packed cell volume (PCV) was according to Ekaidemet al., (2006).

\section{Statistical analyses}

Statistical analysis was performed using SPSS Statistics Version 20 software. Data obtained was expressed as mean \pm standard error of the mean (SEM). The student'st-test was conducted to determine significant differences and $p$ values for significant difference between the mean of control and test groups was considered at $\mathrm{p}<0.05$.

\section{Results}

Table 1: Effect of Ethanol Extract of Leptadeniahastataon biochemical parameters of wistar rats Treatment (mg/kg body weight)

\begin{tabular}{|l|l|c|c|c|}
\hline Parameters & Control & $\mathbf{1 0 0}$ & $\mathbf{2 0 0}$ & $\mathbf{4 0 0}$ \\
\hline AST (U/L) & $102.53 \pm 3.14$ & $96.95 \pm 32.22$ & $32.78 \pm 1.18^{*}$ & $32.45 \pm 4.24^{*}$ \\
\hline ALT (U/L) & $149.66 \pm 3.20$ & $142.10 \pm 3.20$ & $134.19 \pm 3.24^{*}$ & $114.02 \pm 9.87^{*}$ \\
\hline ALP (U/L) & $64.58 \pm 10$ & $55.52 \pm 0.97$ & $72.09 \pm 14.57$ & $90.75 \pm 14.56$ \\
\hline Albu (g/l) & $46.20 \pm 0.69$ & $46.48 \pm 0.42$ & $50.14 \pm 1.30^{*}$ & $50.19 \pm 0.38^{*}$ \\
\hline T.prot (g/l) & $60.34 \pm 1.73$ & $65.17 \pm 1.09$ & $73.17 \pm 2.74^{*}$ & $74.77 \pm 1.23^{*}$ \\
\hline T.bil (mg/dl) & $1.10 \pm 0.04$ & $1.18 \pm 0.07$ & $1.23 \pm 0.11$ & $1.22 \pm 0.05$ \\
\hline D.bil (mg/dl) & $0.66 \pm 0.06$ & $0.94 \pm 0.17$ & $0.72 \pm 0.08$ & $0.68 \pm 0.08$ \\
\hline Urea (mg/dl) & $7.81 \pm 0.16$ & $7.22 \pm 0.20$ & $5.60 \pm 0.80^{*}$ & $4.01 \pm 0.28^{*}$ \\
\hline Creat (mg/dl) & $70.93 \pm 4.38$ & $64.70 \pm 1.41$ & $66.71 \pm 0.38$ & $69.26 \pm 3.32$ \\
\hline
\end{tabular}

Values presented as Mean $\pm \operatorname{SEM}(n=6)$.

* Significantly different compared to control $(\mathrm{P}<0.05)$.

Table 2: The Effect of ethanol extract of Leptadeniahastataon PCV and $\mathrm{Hb}$ of albino rats

\begin{tabular}{|c|c|c|}
\hline Treatment & $P C V(\%)$ & $H b(g / d l)$ \\
\hline Normal Control & $38.67 \pm 0.99$ & $12.88 \pm 0.33$ \\
\hline $100 \mathrm{mg} / \mathrm{kg}$ b.wt & $40.80 \pm 0.31$ & $13.60 \pm 0.11$ \\
\hline $200 \mathrm{mg} / \mathrm{kg}$ b.wt & $41.60 \pm 1.28^{*}$ & $13.88 \pm 0.43$ \\
\hline $400 \mathrm{mg} / \mathrm{kg}$ b.wt & $43.60 \pm 0.42^{*}$ & $14.53 \pm 0.14^{*}$ \\
\hline
\end{tabular}

Values presented as Mean $\pm \operatorname{SEM}(n=6)$.

* Significantly different compared to control $(\mathrm{P}<0.05)$.
Keys: $\mathrm{PCV}=$ Packed cell volume

$\mathrm{Hb}=$ Haemoglobin

\section{Volume 5 Issue 1, January 2016}




\section{International Journal of Science and Research (IJSR) \\ ISSN (Online): 2319-7064 \\ Index Copernicus Value (2013): 6.14 | Impact Factor (2014): 5.611}

\section{Discussion}

The acute toxicity study showed that the ethanol extract of Leptadeniahastatademonstrated high safety margin since the animals tolerated up to $5000 \mathrm{mg} / \mathrm{kg}$ body weight of the extract orally. Similarly, no mortality and changes in the behavioural, neurological and autonomicprofile were observed in treated groups of the rats up to highest dose of $5000 \mathrm{mg} / \mathrm{kg}$ body weight. This revealed that short term use for this purpose is apparently safe. The high safety margin through oral route justified its therapeutic use by the traditional healers.

Chronic toxicity studies in animals are of value in predicting potential toxic effects of a substance or a plant extract from which the response may be correlated with human. It also gives an idea about the organ system involvement (Kalaiselviet al., 2013). Serum marker enzymes are biochemical parameters associated with health indices and are of diagnostic significance in routine clinical evaluation of the state of health. Alanine amino transaminase (ALT) and Aspartate amino transaminase (AST) are largely used in the assessment of liver damage by drugs or any other hepatotoxin (Ramaiah, 2011). The liver and heart release ALT and AST and an elevation in their serum concentrations are indicators of liver and heart damage (Wasanet al., 2001; Mythilypriyaet al., 2007). However, ALT is more specific to the liver and is thus a better parameter for detecting liver injury (Patrick et al., 2012). In this study, serum aspartate aminotransferase (AST) and alanine phosphatase (ALP) of treated animals significantly $(p<0.05)$ decreased while in alanine aminotransferase (ALT) there is no significant compared to the control. The significant decrease in serum AST and ALT activity that was observed in the treated groups is suggestive that ethanol extract of Leptadeniahastata may not possess hepatotoxic effect and equally could not have caused some toxic effects on the heart tissue (Patrick et al, 2012). The non-significant increase in the level of ALP in the group administered 400 $\mathrm{mg} / \mathrm{kg}$ body weight of Leptadeniahastata ethanol extract could be related to the functioning of hepatocytes and an increase in its activity may be due to its increased synthesis in the presence of increased pressure (Manjunathaet al., 2005).

The serum albumin and Total proteins of the treated animals showed significant $(\mathrm{p}<0.05)$ increase compared to the control. The major components of serum proteins include albumin and globulins and liver is the organ, mainly responsible for formation of plasma albumin and at least $30 \%$ serum globulins. Total protein measurements can reflect nutritional status and may be used to screen for and help diagnose kidney and liver diseases and many other conditions (Thierry et al., 2011). Decreased levels of serum proteins are found in renal disease, malnutrition, albuminuria and terminal liver failure. A decrease in total protein is also observed when hepatic function is normal but the proteins are lost in the urine (American society for clinical pathology, 2014).Although the concentration of the serum albumin is reduced in severe liver disease, which of the globulins is usually increased so that the total protein concentration is rarely low. There were no significant change in total and direct bilirubin, hence jaundice could not be resulted in the intake of this extract (Sahaet al, 2010).

It is well known that almost all drugs, chemicals, xenobiotics are eliminated through renal excretion hence it is necessary to estimate the effects of ethanol extract on kidney functions. Urea and creatinineare used to assess the renal damage and are elevated if there is any renal damage. There was no significant change in the serum levels of creatinine of the treated animals, while there were insignificant $(p<0.05)$ decrease in serum urea at dose 200 $\mathrm{mg} / \mathrm{kg}$ body weight and $400 \mathrm{mg} / \mathrm{kg}$ body weight compare to the control group. Urea is the main product of protein catabolism. Amino acid deamination takes place in the liver, which is also the site of urea cycle, where ammonia released is converted into urea and is excreted through urine. It represents $90 \%$ of the total urinary nitrogen excretion. Urea varies directly with protein intake and inversely with the rate of excretion. Some of the urea is bound to hemoglobin, so its concentration in the red cells is greater than that in the plasma. Renal diseases, which diminish the glomerular filtration, lead to urea retention and decrease in urea is seen in severe liver disease with destruction of cells leading to impairment of the urea cycle (Ranjna, 1999). Creatinine is a waste product formed in muscle by creatine metabolism. Creatineis synthesized in the liver, passes into the circulation and is taken up almost entirely by skeletal muscles.

The haematopoietic system is one of the most responsive targets for toxic compounds and an important manifestation of physiological and pathological status in man and animals (Manas, et al., 2011). The ethanol extract of Leptadeniahastatashow significant $(\mathrm{p}<0.05)$ increase in the level of PCV and haemoglobin count $(\mathrm{Hb})$ in the treated rats when compared to the normal. The slight increase in PCV and $\mathrm{Hb}$ count may be an indication that the plant extract could boost blood production when consumed within certain limits. This increase however may be a positive factor in boosting blood parameters in anaemic patients. This result may underscore the local use of this plant as blood booster in anemic patients. Since higher PCV and $\mathrm{Hb}$ values were obtained in the test groups than the control, we may therefore suggest that this plant can use as possible haematenic agent in the treatment of anaemia.

\section{Conclusion}

The present findings have shown that Leptadeniahastata is not likely to produce severe toxicological risk. However, a conclusive remark can only be made on the safety profile of the drug after further investigations of the observations made in this study at the cellular level in a chronic study. Furthermore, the present study of the phytochemical constituents has authenticated its usefulness by traditional herbalists in ethnomedicine.

\section{References}

[1] Alisi, C. S., Onyeze, G. O. C. (2008). Nitric oxide scavenging ability of ethyl acetate fraction of methanolic leaf extracts of Chromolaenaodorata. African Journal of Biochemistry Research. 2(7): 145150. 


\section{International Journal of Science and Research (IJSR) \\ ISSN (Online): 2319-7064}

Index Copernicus Value (2013): 6.14 | Impact Factor (2014): 5.611

[2] Arthur, C.G, \& John, E.H. (2000) Textbook of Medical Physiology. Edition 10, Philadelphia: W.B. Sounders, 279-281.

[3] Bayala, B., Telefo, P.B., Bassole, I.H.N., Tamboura, H.H., Belemtougri, R.G., et al. (2011) Antispermatogenic activity of Leptadeniahastata(Pers.) Decne leaf stems aqueous extracts in male Wistar rats. Journal of Pharmacology and Toxicology. 6: 1-9.

[4] Debjani, N and Manas, K. M, (2011) Phytochemical Screening and Toxicity Study of Saracaasoca Bark Methanolic Extract.International Journal of Phytomedicine 3:498-505

[5] Doumas, B. T. (1975). Standards for total serum protein assays-a collaboration study: Clinical chemistery.21: 1159-1166.

[6] Drotman, R. B., and Lawhorn, G. T. (1978). Serum enzymes as indicators of chemical- induced liver damage. Drug and Chemical Toxicology. 1: 163-171.

[7] Freiberger, C. E, Vanderjagt, D. J., Pastuszyn, A., Glew, R. S., Mounkaila, G., Millson, M., Glew, R. H. (1998).Nutrients contents of seven edible leaves of seven wild plants from Niger.Plant Foods for Human Nutrition. 53(1): 57-69.

[8] Handa, S.S., Khanuja, S.P.S., Longo, G., and Rakesh D.D. (2008).Extraction technologies for medicinal and aromatic plants, (United Nations Industrial Development Organization and the International Centre for Science and High Technology

[9] Hutchinson, J. and Dalziel, J.M. (1937).Leptadenia, the useful plants of tropical Africa. London (1): 387-388.

[10] Kalaiselvi, P., Lakshmidevi, E., Thulasiraman, K., Suresh, M and Uma, M (2013). Chronic toxicity studies of aqueous leaf extract of Indian traditional medicinal plant Ocimuntenuiflonim (Linn) in rats. European Journal of Experimental Biology. 3(5):240-247.

[11]Kerarho, J., and Adam, J.G. (1974). The traditional Senegalese pharmacopoeia: Medicinal and poisonous plants.Vigot brother's edition, Paris.

[12] Manjunatha, B.K, Vidya, S.M., Dhiman, P., Pallav, I. R. (2005). Hepatoprotective activity of Leucashirtaagainst $\mathrm{CCl} 4$ induced hepatic damage in rats. Indian Journal of Experimental Biology.;43:722-7

[13] Navarro, V. J. (2006). Drug-related hepatotoxicity.New England Journal of Medicine.354:731-739.

[14] Nikiema, J. B., Vanhaelen-Fastre, R., Vanhaelen, M., Fontaine, J., Gracf, C. D. E. and Heena, M. (2001). Effects of anti-inflammatory triterpenes isolated from Leptadeniahastata latex on keratinocytes proliferation. Phytotherapeutic Research, 15 (2): 131 -134.

(2008).OECD Guideline for Testing of Chemicals (TG 407).Repeated Dose 28-Day Oral Toxicity Study in Rodents.OECD/OEDC. 36(5): 303 - 305

[16] Patrick-Iwuanyanwu, K.C., Amadi, U., Charles, I.A., Ayalogu, E.O. (2012). Evaluation of acute and subchronic oral toxicity study of baker cleaners bittersa polyherbal drug on experimental rats. Experimental and clinical Science Journal.11:632-640

[17] Priya, P., Shoba, F.G., Parimala, M and Sathya, J. (2014) Antioxidant and antibacterial properties of Manilkarazapota(L) royen flower. International
Journal of Pharmaceutical and Clinical Research. 6(2):174-178.

[18] Raja, S., Ahmed, N., Kumar, V., Mukherjee, K., Bandyopadhyan, A., Mukherjee, K. P. (2007). Antioxidant effect of Cysticusscoparius against carbon tetrachloride treated liver injury in rats. Journal of Ethnopharmacology.109: 41-47.

[19] Ramaiah, S.K. (2011). Preclinical safety assessment: current gaps, challenges and approaches in identifying translatable biomarkers of druginduced liver.Clinical Laboratory Medicine; 31:161-72.

[20]Ranjna, C. (1999). Practical Clinical Biochemistry Methods and Interpretation.2nd Edition, p. 117.

[21] Reinhold, J.G. (1953). Manual determination of serum total protein, albumin and globulin fractions by biuret method In; standard methods in clinical chemistry, Reiner, M (Ed) Academic press, New York pp 88-97.

[22] Reitman, S. and Frankel, S. (1957).Colorimetric Point Methods Method for the determination of Serum glutamic Oxaloacetate and Glutamic Pyruvic Transaminases.American Journal of Clinical Pathology.28:56.

[23] Saha, P., Mazumder, U.K. and Haldar, P.K. (2010). Acute and subchronic toxicity of C. maxima Aerial parts.International Journal of Research. In Pharmaceutical and Biomedical Science., 2(2):634639.

[24] Sena, L.P., Vanderjagt, D. J, Rivera, C., Tsin, A. T., Muhamada, I., Millson, M., Pastuszyn, A, and Glew, R.H (1998).Analysis of nutritional component of eight famine foods of the republic of Niger.Plant Foods for HumanNutrition 52(1): 17- 30.

[25] Thierry, T.A., Acha, A.E., Paulin, N., Aphrodite, C. Pierre, K. and Tazoacha, A. (2011).Subacute toxicity study of the aqueous extract from Acanthusmontanus.Electronic Journal of Biology; $7(1): 11-5$.

[26] United State National Institute for Health. (1985). Publication no: 85-23

[27] Weatherburn, M.W. (1967).Urease-Berthelot colorimetric methods for Serum urea Determination.Analytical chemistry.39:971. 